\title{
MENINGKATKAN HASIL BELAJAR IPA SISWA DENGAN MENGGUNAKAN MODEL PEMBELAJARAN KOOPERATIF TIPE STAD KELAS V SD ST. ANTONIUS BANGUN MULIA TAHUN PELAJARAN 2017/2018
}

\section{OLEH: \\ YUNIKO JULIANA SIREGAR (PGSD FKIP UNIVERSITAS KATOLIK SANTO THOMAS SU)}

\begin{abstract}
This research is intended to improve science learning outcomes by using STAD type cooperative learning model in grade V students of St. Antonius BangunMulia academic year 2017/2018. Subjects in doing this action are the researchers who work together with the homeroom as observers, while the object of this research is the students of grade V SD St. Antonius BangunMulia Medan which requires 35 students consisting of 15 men and 20 women. Data processing techniques through observation of the results of learning tests and student learning activities. The results of this study indicate an increase in student learning outcomes in science subjectspda material digestive system food in human class V St. Antonius BangunMulia Medan. This is evident from the results of research conducted on the pretest of students who get the complete value of 5 people or $14.29 \%$ while students who are not complete as many as 30 people or $85.71 \%$. So began the research on the first cycle of students who got the complete value of 21 people or $60 \%$ while the unfinished students as many as 14 people or $40 \%$, then an increase in the cycle I compared to the pretest. Will not meet the completed category of mastery already in the set. So began the research on cycle II of students who get thoroughly as many as 30 people or $85.71 \%$ while students who are not complete as many as 5 people or $14.29 \%$, then there is an increase in cycle II depending on the cycle I and already meet the specified mastery. Furthermore, teacher activity on observation I giving cycle average of $60 \%$ and in cycle II has increased to $86 \%$. While the student activity on the learning process resulted in an average of $60 \%$ and in cycle II has increased to $82 \%$. Thus developed by using cooperative learning model type STAD science subjects on food system material in human grade V SD St. Antonius BangunMulia Medan can improve student learning outcomes. therefore it is recommended for subsequent learning to use STAD type cooperative learning model so that student learning outcomes can be improved.
\end{abstract}

Keywords: Student Learning Outcomes, Science Subjects, STAD Type Cooperative Learning Model.

\section{PENDAHULUAN}

\section{Latar Belakang Masalah}

Pendidikan merupakan kualitas Sumber Daya Manusia (SDM) yang penting dalam meningkatkan dan menjamin keberlangsungan pembangunan suatu bangsa.Selain itu, pendidikan dapat mengembangkan pribadi anak dan membangun dirinya agar ikut serta bertanggung jawab terhadap pengembangan 
kemajuan bangsa dan Negara.Hal ini sebagaimana dikemukakan Shoimin (2016:15) bahwa pendidikan nasional adalah pembangunan sumber daya manusia yang mempunyai peranan penting bagi kesuksesan dan kesinambungan pembangunan nasional.Pendidikan merupakan satu-satunya aset untuk membangun sumber daya manusia yang berkualitas.

Pendidikan sangat besar pengaruhnya terhadap perkembangan dan perwujudan diri individu. Manusia tumbuh dan berkembang melalui proses belajar, untuk mewujudkan proses pembelajaran tersebut dituntut adanya upaya guru untuk mengembangkan kemampuannya secara professional. Peningkatkan mutu pendidikan, seorang guru tidak hanya memiliki jenjang pendidikan yang tinggi tetapi dituntut untuk menciptakan kegiatan pembelajaran kreatif dan inovatif.Pernyataan tersebut sesuai dengan pendapat Trianto (2011:1) mengatakan bahwa pendidikan yang baik adalah pendidikan yang tidak hanya mempersiapkan para siswanya untuk sesuatu profesi atau jabatan, tetapi menyelesaikan masalahmasalah yang dihadapi dalam kehidupan sehari-hari.

Salah satu masalah yang dihadapi dunia pendidikan adalah masalah lemahnya proses pembelajaran, karena pembelajaran merupakan inti dari proses pendidikan.Sistem pendidikan disebut bermutu dari segi proses jika proses belajar mengajar berlangsung secara efektif dan efisien. Pendidikan bertujuan untuk mengembangkan potensi pesertadidik agar menjadi manusia yang beriman dan bertakwa kepada Tuhan Yang Maha Esa, berahlak mulia, sehat, berilmu, cakap, kreatif, mandiri, dan menjadi warga negara yang demokratis secara bertanggung jawab.

Pentingnya pendidikan terhadap perkembangan ilmu pengetahuan dan teknologi.Salah satu mata pelajaran yang erat dengan perkembangan ilmu pengetahuan dan teknologi adalah mata pelajaran IPA.Ilmu Pengetahuan Alam (IPA) sering juga disebut dengan istilah Sains.Pada dasarnya pembelajaran IPA merupakan pembelajaran yang menarik dan menyenangkan untuk dipelajari karena dapat dihubungkan dengan kehidupan sehari-hari.Pembelajaran IPA juga membawa siswa untuk dapat memiliki sikap, minat untuk mengenal dan mempelajari benda-benda serta kejadian dilingkungan sekitarnya.Belajar IPA dapat memberikan (kognitif); sikap ilmiah (afektif); keterampilan (psikomotorik), pemahaman kebiasaan dan apresiasi.Oleh karena itu, guru perlu merancang suatu pembelajaran yang menarik serta berpusat pada siswa, sehingga tujuan yang ingin dicapai dalam pembelajaran IPA dapat tercapai.

Untuk mencapai tujuan pembelajaran IPA guru hendaknya dapat menciptakan kondisi dan situasi pembelajaran yang membuat siswa aktif dalam membentuk, menemukan, dan mengembangkan pengetahuannya.Oleh karena itu guru dituntut untuk mampu mengelola kegiatan pembelajaran secara sistematis serta mampu menciptakan kondisi belajar yang efektif dan efisien selama proses pembelajaran berlangsung. Salah satu faktor yang mendukung keberhasilan guru dalam mengelola pembelajaran adalah kemampuan guru menentukan kualitas pembelajaran IPA dalam merencanakan dan melaksanakan pembelajaran itu sendiri. Perencanaan tersebut meliputi penggunaan media dan model pembelajaran yang sesuai dengan karasteristik materi yang akan diajarkan.

Namun kenyataanya banyak siswa memandang pembelajaran IPA sebagai bidang studi yang paling sulit dan membosankan karena rendahnya 
penguasaan siswa terhadap pembelajaran IPA.Hal ini dikemukakan oleh Susanto (2016:165) bahwa Ilmu Pengetahuan Alam (IPA) merupakan mata pelajaran yang selama ini dianggap sulit oleh sebagian besar pesertadidik mulai dari jenjang pendidikan sekolah dasar, sampai sekolah menengah.

Berdasarkan wawancara peneliti dengan guru mata pelajaran IPA, bahwa masalah yang dihadapai siswa dalam pembelajaran IPA adalah kurangnya antusias siswa selama proses pembelajaran berlangsung. Siswa lebih cenderung menerima apa saja yang disampaikan guru, sehingga siswa diam dan enggan dalam menggungkapkan pernyataan maupun pendapat. Hal ini disebabkan penggunaan metode ceramah yang terlalu sering digunakan tanpa menggunakan model pembelajaran yang menarik.Hal ini tampak dari rata-rata hasil belajar pesertadidik yang masih memprehatinkan, dan dapat dilihat pada hasil nilai UTS pada mata pembelajaran IPA kelas V SD St.Antonius Bangun Mulia Medan Tahun Pembelajaran 2015/2016. Hal ini terbukti seperti yang tergambar pada Tabel 1.1 dibawah ini.

Tabel 1.1 Nilai UTS IPA Siswa Kelas V SD St. Antonius Bangun Mulia TahunPembelajaran 2015/2016

\begin{tabular}{|l|l|l|}
\hline Nilai KKM & Jumlah Siswa & Persentase (\%) \\
\hline$\geq 70$ & 14 & $32 \%$ \\
\hline$\leq 70$ & 30 & $68 \%$ \\
\hline Jumlah & 44 & $100 \%$ \\
\hline
\end{tabular}

Sumber: Daftar Nilai UTS pada mata pelajaran IPA kelas V SD St. Antonius Bangun Mulia.

Berdasarkan data tabel 1.1 tersebut dapat dilihat bahwa siswa kelas V memiliki nilai yang belum optimal. Hal ini dilihat dari 44 siswa hanya 14 orang siswa yaitu sebesar $32 \%$ yang memenuhi KKM yang telah ditetapkan, sedangkan jumlah siswa yang tidak memenuhi KKM adalah 30 orang siswa yaitu $68 \%$. Sedangkan Kriteria Ketuntasan Minimal (KKM) untuk mata pelajaran IPA dikelas V SD St. Antonius Bangun Mulia adalah 70.

Dari penjelasan tersebut dapat disimpulkan bahwa kegiatan pembelajaran IPA masih berjalan secara konvensional, dimana pembelajaran masih bersifat satu arah, sehingga proses pembelajaran berpusat pada guru dan pemberian tugas tanpa menggunakan model pembelajaran yang baik, dan membuat siswa merasa bosan dan banyak siswa yang bermain-main selama proses pembeajaran berlangsung. Selain itu siswa hanya duduk diam tanpa merespon apa yang disampaikan oleh gurunya. Oleh karena itu sangatlah penting untuk menggunakan model pembelajaran di dalam kelas sehingga terjadinya hubungan timbal balik baik antara guru dengan siswa maupun siswa dengan siswa dan pembelajaranpun akan lebih terarah sehingga siswa lebih mudah dalam memahami pembelajaran yang telah disampaikan oleh guru. Salah satunya ialah dengan menggunakan model pembelajaran yang melibatkan siswa secara aktif dalam kegiatan belajar mengajar.

Untuk meningkatkan hasil pembelajaran siswa yaitu dengan menggunakan model pembelajaran kooperatif tipe Student Teams Achievement devision (STAD), karena yang menjadi keunggulan dari model pembelajaran kooperatif tipe Student Teams Achievement devision (STAD)(1)Siswa dapat menyampaikan ide-ide atau gagasannya, (2) Dapat melatih keberanian siswa, 
(3)Dapat melatih kemandirian siswa, dan (4) Siswa dapat saling mebantu, siswa yang pandai dapat membantu siswa yang kurang mampu. Model pembelajaran kooperatif tipe Student Teams Achievement devision (STAD) merupakan salah satu model pembelajaran kooperatif yang paling sederhana.Selain itu pembelajaran kooperatif tipe Student Teams Achievement devision(STAD) siswa dibagi menjadi kelompok yang beranggotakan 4-5 orang yang memiliki keberagaman kemampuan, jenis kelamin dan sukunya. Model pembelajaran kooperatif tipe Student Teams Achievement devision (STAD) dikatakan cocok untuk digunakan dalam pembelajaran IPA karena model ini membawa siswa untuk saling bekerja sama dan ikut berperan aktif dalam meningkatkan kebehasilan pembelajaran siswa dan model ini juga dapat meningkatkan kemampuan siswa dalam mengeluarkan pendapat. Selain itu model pembelajaran kooperatif tipe STAD memacu pada siswa agar saling mendorong dan membantu satu sama lain untuk menguasai keterampilan yang diajarkan oleh guru.

Adapun model pembelajaran kooperatif tipe Student Teams Achievement devision (STAD) pada pelajaran IPA guru dapat melakukan kuis yang berhubungan dengan materi yang sudah dijelaskan sebelumnya, pada saat kuis berlangsung peserta didik tidak diperbolehkan untuk saling membatu agar guru mengetahui sejauh mana siswa memahami materi yang telah disampaikan oleh guru secara perindividu.

Berdasarkan uraian tersebut, maka peneliti tertarik melakukan suatu penelitian dengan penerapan metode pembelajaran dalam bentuk Penelitian Tindakan Kelas (PTK) dengan judul "Meningkatkan Hasil Belajar IPA Siswa dengan Menggunakan Model Pembelajaran Kooperatif Tipe Student Teams Achievement devision (STAD) Kelas V SD St. Antonius Bangun Mulia Tahun Pembelajaran 2017/2018."

\section{Identifikasi Masalah}

Berdasarkan latar belakang masalah di atas, maka yang menjadi identifikasi masalah dalam penelitian ini adalah:

1. Rendahnya penguasaan siswa terhadap pembelajaran IPA.

2. Guru kurang menarik dalam menyampaikan materi sehingga pembelajaran terasa membosankan.

3. Pembelajaran masih berpusat pada guru.

4. Proses pembelajaran IPA belum berjalan dengan baik.

5. Kurangnya antusias siswa selama proses pembelajaran berlangsung.

6. Metode pembelajaran kurang melibatkan siswa secara aktif dalam kegiatan pembelajaran.

7. Hasil belajar siswa rendah

\section{Pembatasan Masalah}

Berdasarkan uraian pada latar belakang dan identifikasi masalah diatas, perlu dilakukan pembatasan masalah agar peneliti lebih terarah dan terfokus pada masalah yang diteliti.Oleh karena itu yang menjadi batasan masalah dalam penelitian ini adalah: "penggunaan model pembelajaran kooperatif tipe Student Teams Achievement devision (STAD)untuk meningkatkan hasil belajar IPAsiswa pada materi sistem pencernaan makanan pada manusia di kelas V SD St. Antonius Bangun Mulia Medan Tahun Pembelajaran 2017/2018”.

Perumusan Masalah 
Berdasarkan pembatasan masalah yang dikemukakan di atas maka rumusan masalah dalam penelitian ini adalah:

1. Bagaimanakah proses pelaksanaan pembelajaran dengan menggunakan model pembelajaran kooperatif tipe Student Teams Achievement devision (STAD) untuk meningkatkan hasil belajar IPA pada materi sistem pencernaan makanan pada manusia di kelas V SD St. Antonius Bangun Mulia Tahun Pembelajaran 2017/2018?

2. Apakah dengan menggunakan model pembelajaran kooperatif tipe Student Teams Achievement devision (STAD) dapat meningkatkan hasil belajar IPA siswa kelas V SD St. Antonius Bangun Mulia Tahun Pembelajaran 2017/2018?

\section{Tujuan Penelitian}

Adapun tujuan penelitian ini adalah untuk memperoleh masukan tentang penggunaan model pembelajaran kooperatif tipe STAD yaitu:

1. Untuk mengetahui pelaksanaan pembelajaran dengan menggunakan model pembelajaran kooperatif tipe Student Teams Achievement devision (STAD) pada materi sistem pencernaan makanan pada manusia pada mata pelajaran IPA kelas V SD St. Antonius Bangun Mulia Tahun Pelajaran 2017/2018.

2. Untuk meningkatkan hasil belajar IPA dengan menggunakan model pembelajaran kooperatif tipe Student Teams Achievement devision (STAD) pada materi sistem pencernaan makanan pada manusia di kelas V SD St. Antonius Bangun Mulia Tahun Pelajaran 2017/2018.

\section{Manfaat Penelitian}

Adapun hasil penelitian ini akan bermanfaat bagi pengelolaan pembelajaran Ilmu Pengetahuan Alam (IPA) yaitu:

1. Bagi Siswa

2. Bagi Guru

3. Bagi Sekolah

4. Bagi Peneliti

\section{METODOLOGI PENELITIAN} Pendekatan dan Metode Penelitian

\section{Pendekatan}

Dalam penelitian ini, peneliti menggunakan pendekatan campuran.Pendekatan campuran merupakan gabungan dari dua metode yaitu pendekatan kuantitatif dan pendekatan kualitatif.Selain itu, dengan menggunakan pendekatan campuran peneliti dapat memperoleh hasil-hasil statistik dari suatu sampel, kemudian menindaklanjutinya dengan observasi sejumlah individu untuk membantu menjelaskan lebih jauh hasil saintifik yang diperoleh.

Metode Penelitian

Metode atau jenis penelitan yang dilakukan merupakan Penelitian Tindakan Kelas (PTK) karena pada penelitian ini bertindak secara langsung dalam penelitian.Pemilihan metode ini di dasari sebagai upaya peningkatan efektifitas pembelajaran yang berlangsung dalam tahap siklus.Penelitian Tindakan Kelas (PTK) bermula dari suatu perencanaan, pelaksanaan, pengamatan, dan refleksi. Penelitian ini bertujuan untuk meningkatkan hasil belajar IPA siswa di kelas V SD 
St. Antonius Bangun Mulia Medan dengan menggunakan model pembelajaran kooperatif tipe STAD tahun pembelajaran 2017/2018.

\section{Lokasi dan Jadwal Penelitian}

\section{Lokasi Penelitian}

Penelitian ini dilakukan di kelas V SD St. Antonius Bangun Mulia tahun pembelajaran 2017/2018 Medan, yang beralamat di J1. Sisingamangaraja Km 11 No 68 yang berdiri pada tahun 1986.Alasan melakukan penelitian disekolah ini, karena berdasarkan wawancara peneliti dengan guru mata pelajaran IPA bahwa terdapat masalah rendahnya hasil belajar siswa pada mata pelajaran IPA dengan materi sistem pencernaan pada manusia.

\section{Jadwal Penelitian}

Waktu penelitian ini dilakukan pada mulai Mei sampai pelaksanaan tindakan selesai.

\section{Subjek Penelitian}

Subjek dalam penelitian ini adalah siswa-siswi kelas V SD St. Antonius Bangun Mulia Medan tahun pembelajaran 2017/2018. Penelitian ini direncanakan mulai dari bulan Mei sampai dengan bulan Oktober 2017. Dengan jumlah siswa 35 orang, 20 orang perempuan dan 15 orang laki-laki.Sedangkan objek penelitian adalah meningkatkan hasil belajar IPA siswa pada materi sistem pencernaan makanan pada manusia dengan menggunakan model pembelajaran kooperatif tipe STAD.

\section{Jenis dan Sumber Data}

\section{Jenis Data}

Jenis penelian ini meliputi metode kualitatif dan kuantitatif.

Kualitatif yaitu suatu penelitian yang bersifat menggambarkan kenyataan atau fakta sesuai dengan data yang diperoleh, dengan tujuan untuk mendeskripsikan aktivitas guru dan siswa selama proses pembelajaran.

Kuantitatif adalah suatu penelitian yang memberikan nilai berupa angka pada aktifitas guru dan siswa selama penelitian.

\section{Sumber Data}

Sumber data yang diperlukan berasal dari dua sumber yaitu:

Guru, Dalam penelitian ini, peneliti mendapatkan informasi dari guru wali kelas V SD St. Antonius Bangun Mulia Medan, dimana peneliti mendapatkan informasi melalui wawancara, dan observasi

Sekolah, Sekolah merupakan tempat dimana peneliti akan melakukan penelitian selama penelitian berlangsung. Sekolah merupakan tempat untuk mendapatkan data-data yang dibutuhkan peneliti yang berupa data-data nilai, buku.

Dokumen daftar nilai pembelajaran IPA Kelas V SD St. Antinius Bangun Mulia Medan.

\section{Teknik dan Alat Pengumpulan Data}

Teknik pengumpulan data dalam penelitian ini adalah observasi, dan tes sebagai berikut:

\section{Observasi}

Observasi merupakan teknik pengumpulan data dengan cara mengamati setiap kejadian yang sedang berlangsung dan mencatat dengan alat observasi tentang hal-hal yang akan diteliti. Observasi juga berhubungan dengan kegiatan 
siswa dan guru. Selain itu observasi dapat dilakukan untuk mengumpulkan informasi tentang kegiatan guru dan siswa dalam kegiatan proses pembelajaran.

\section{Tes}

Tes merupakan pengumpulan data untuk mengukur kemampuan siswa dalam aspek kognitif, atau tingkat penguasaan materi pembelajaran. Selain itu pengumpulan data melalui tes dilakukan sendiri oleh peneliti pada kelas yang dijadikan sampel yaitu untuk melihat tingkat kemampuan siswa dalam menjawab soal-soal yang berhubungan dengan sistem pencernaan makanan pada manusia.Tes yang dilakukan dalam penelitian ini berupa tes tertulis.Tes tertulis berupa pertanyaan-pertanyaan untuk mengetahui aspek-aspek tingkat kemampuan yang dalam menjawab dan memahami pertanyaan tersebut.

\section{Uji Validitas Data, Reabilitas \&Instrumen}

\section{Uji Validitas}

Sebelum instrumen diuji cobakan, terlebih dahulu dilakukan validitas terhadap instrumen tes dan perangkat pembelajaran (RPP) serta lembar instumen pendukung penelitian (lembar observasi aktivitas guru dan siswa) pada proses pembelajaran dengan menggunakan model pembelajaran kooperatif tipe STAD untuk mengetahui validitas dari soal tersebut maka digunakan rumusan sebagai berikut:

$r_{x y}=\frac{n \sum x y-\sum x \sum y}{\sqrt{\left.\ln \sum x^{2}-\left(\sum x\right)^{2}\right)\left(n \sum y^{2}-\left(\sum y\right)^{2}\right)}}$ Arikunto

\section{(2016:87)}

Keterangan:

$r_{x y} \quad$ : koefisien validitas.

$\mathrm{N} \quad$ : Banyaknya subjek.

$\mathrm{X}$ : Nilai perbandingan.

Y : Nilai dari instrumen yang akan dicari validitasnya.

Uji validitas pada spss for windows 22 menggunakan Product Moment Pearson Correlaction yang merupakan nilai $r_{\text {hitung }}$ untuk masing-masing pertanyaan $r_{\text {hitung }}>r_{\text {tabel }}$ dengan taraf signifikans $\alpha=0.05$

Adapun criteria pengujian validitas:

Jika nilai $r_{\text {hitung }}>r_{\text {tabel }}$, berarti data valid

Jika nilai $r_{\text {hitung }}<r_{\text {tabel }}$, berarti data tidak valid

Interpretasi terhadap nilai koefisien korelasiJika nilai $r_{x y}$ di gunakan kriteria Nurgana (Haris dan Jihad 2013:180) sebagai berikut:

$0.80<r_{x y} \leq 1.00$ : validitas sangat tinggi

$0.60<r_{x y} \leq 0.80$ : validitas tinggi

$0.40<r_{x y} \leq 0.60$ : validitas cukup

$0.20<r_{x y} \leq 0.40$ : validitas rendah

$r_{x y} \leq 0.20 \quad$ : validitas sangat rendah

\section{Reliabilitas}

Pengujian reabilitas dapat dilakukan dengan teknik belah dua hal ini sebagaimana dikemukakan oleh Suginyono (2012:185) bahwa pengujian reliabilitas dapat dilakukan dengan teknikbelah dua dari Spearman Brown dengan rumus sebagai berikut: 
$r_{11}=\frac{n}{n-1}\left(1-\frac{\sum \sigma_{1}^{2}}{\sigma_{t}^{2}}\right)$

Keterangan:

$r_{11}=$ Koefisien reabilitas alat evaluasi

$\mathrm{n} \quad=$ Banyaknya item

$\sum \sigma_{1}^{2}=$ Jumlah varians skor tiap-tiap item

$\sigma_{t}^{2} \quad=$ Varians skortotal

Uji reliabilitas ini dapat di lakukan pada spss for windows 22 menggunakan cronbach Alpha di lihat pada kolom corrected intem - total correlation dengan taraf signifikans $\alpha=0.05$

Kriteria koefisien reliabilitas terhadap nilai koefisien korelasi $r_{11}$ mengacu pada pendapat Guilford ( Haris dan Jihad 2013: 181) sebagai berikut:
$0.90<r_{11} \leq 1.00 \quad$ : Reabilitas sangat tinggi
$0.70<r_{11} \leq 0.90 \quad$ : Reabilitas tinggi
$0.400<r_{11} \leq 0.70 \quad$ : Reabilitas sedang
$0.20<r_{11} \leq 0.40 \quad$ : Reabilitas rendah
$r_{11} \leq 0.20 \quad:$ Reabilitas sangat rendah

\section{Instrumen Data}

Instrumen dalam penelitian yang dilakukan bertujuan untuk memperoleh data tentang kualitas pembelajaran, dan hasil belajar pada mata pelajaran IPA. Selain itu instrumen dilakukan dengan menggunakan model pembelajaran kooperatif tipe STAD pada mata pelajaran IPA dengan materi sistem pencernaan makanan pada manusia pada kelas V SD St. Antonius Bangun Mulia tahun pelajaran 2017/2018 Medan.

\section{Analisis Data}

Analisis data yang digunakan dalam penelitian adalah kualitatif dan kuantitatif. Hal ini sebagaimana dikemukakan oleh Sanjaya (2013:106) yaitu Kualitatif digunakan untuk menentukan peningkatan proses belajar khususnya berbagai tindakan yang dilakukan guru

Kuantitatif digunakan untuk menentukan peningkatan hasil belajar siswa sebagai pengaruh dari setiap tindakan yang dilakukan guru. Analisis data digunakan untuk mengetahui berhasil atau tidaknya tindakan yang dilakukan dalam penelitian. Sesuai dengan tujuan penelitian, maka analisis data yang dilakukan adalah:

\section{Hasil Pelaksanaan Pembelajaran}

Untuk menganalisis data hasil pelaksanaan pembelajaran dengan menggunakan model pembelajaran kooperatif tipe STAD pada mata pelajaran IPA, maka analisis yang dapat dilakukan ialah:

\section{a. Penilaian aktivitas guru}

Untuk menentukan pelaksanaan pembelajaran dengan menggunakan rumus:

$$
\text { Nilai } \%=\frac{\text { Total skor }(\text { perolehan })}{\text { Skor maksimal }} \times 100 \%
$$

(Tambubolon Saur 2013:239)

\begin{tabular}{|l|l|}
\hline Kriteria Penilaian & Keterangan \\
\hline $\mathrm{A}=81-100$ & Baik sekali \\
\hline $\mathrm{B}=61-80$ & Baik \\
\hline
\end{tabular}




\begin{tabular}{|l|l|}
\hline $\mathrm{C}=41-61$ & Cukup \\
\hline $\mathrm{D}=21-40$ & Kurang \\
\hline $\mathrm{E}=0-20$ & Sangat kurang \\
\hline
\end{tabular}

b. Penilaian aktivitas siswa

Untuk mengetahui pelaksanaan pembelajaran aktivitas siswa digunakan rumus:

Nilai $=\frac{\text { Skor yang di peroleh }}{\text { Skor Maksimal }}$ X $100 \%$

Tabel 3.7 Kriteria Penilaian Dalam Pelaksanaan Pembelajaran

(Asep Jihad 2012:131)

\begin{tabular}{|l|l|}
\hline kriteria Penilaian & Keterangan \\
\hline $1=10-20$ & Sangat Kurang \\
\hline $2=30-49$ & Kurang \\
\hline $3=50-69$ & Cukup \\
\hline $4=70-89$ & Baik \\
\hline $5=90-100$ & Baik Sekali \\
\hline
\end{tabular}

\section{Ketuntasan hasil belajar siswa}

\section{a. Ketuntasan individu}

Setiap siswa dikatakan tuntas belajarnya (ketuntasan individu) jika hasil belajar siswa mencapai nilai Kriteria Ketuntasan Minimum (KKM) yang telah ditetapkan disekolah yaitu 70.Untuk menentukan ketuntasan belajar siswa (individu) dapat dihitung dengan menggunakan persamaan sebagai berikut:

$\mathrm{KB}=\frac{t}{t_{t}} \mathrm{X} 100 \%$

Trianto

\section{(2011:241)}

Keterangan:

KB : Ketuntasan belajar

$\mathrm{T} \quad$ : Jumlah skor yang diperoleh siswa

$\frac{T}{T_{t}} \quad$ : Jumlah skor total

\section{b. Ketuntasan Klasikal}

Criteria ketuntasan klasikan adalah jika suatu kelas dikatakan tuntas belajar.Penggunaan model pembelajaran kooperatif tipe STAD dikatakan berhasil jika penggunaan model pembelajaran kooperatif tipe STAD dapat meningkatkan hasil belajar siswa kelas V SD St. Antonius Bangun Mulia pada materi sistem alat pencernaan makanan pada manusia dan hewan.

Ketuntasan klasikal terpenuhi jika suatu kelas dikatakan tuntas belajar di dalam kelas tersebut mencapai 70\% siswa yang sudah tuntas atau 70\% dari jumlah siswa di dalam kelas mendapat Kriteria Ketuntasan Minimum (KKM) yaitu 70.

Untuk menghitung persentase ketuntasan belajar digunakan rumus sebagai berikut:

$\mathrm{P}=\frac{\sum \text { siswa yang tuntas belajar }}{\sum \text { siswa }} \times 100 \%$ (zainal

Aqib,dkk,

2010:205)

Keterangan:

$\mathrm{P}$

: Persentase siswa

Volume: 1 No. 1 Juli 2018

JURNAL ILMIAH AQUINAS TERBIT JULI DAN JANUARI SETIAP TAHUNNYA 
$\sum$ siswa yang tuntas belajar

S siswa

\section{c. Penilaian Rata-rata (Mean)}

Untuk mencari nilai rata-rata dengan menjumlahkan semua skor, kemudian dibagi dengan banyaknya siswa yang memiliki skor tersebut. Hal ini sebagaimana dikemukakan oleh Sudjana ( 2009:109) bahwa nilai rata-rata (mean) merupakan nilai rata-rata yang diperoleh dengan menjumlahkan seluruh skor dibagi dengan banyaknya subjek. Untuk mencari nilai rata-rata digunakan rumus rata-rata yaitu:

$\bar{x}=\frac{\sum \mathrm{X}}{\mathrm{N}}$

Keterangan

$\bar{x} \quad$ : rata-rata (mean)

$\sum x \quad$ : jumlah seluruh skor

$\mathrm{N} \quad$ : banyaknya subjek

\section{Indikator Kinerja Penelitian}

Penelitian tindakan kelas diasumsikan bila dilakukan perbaikan kualitas pembelajaran. Indikator kinerja yang ingin dicapai dalam penelitian ini adalah meningkatkan hasil pembelajaran IPA kelas V SD St. Antonius Bangun Mulia Medan dengan menggunakan model pembelajaran kooperatif tipe STAD sebagai tolak ukur keberhasilan pelaksanaan penelitian tindakan kelas sehingga siswa mampu mencapai nilai Ketuntasan Kriteria Minimum (KKM) yaitu 70 dan persentase ketuntasan siswa 70\%. Jika hasil belajar siswa belum memuaskan akan dilakukan siklus II begitu juga seterusnya.

\section{Prosedur Penelitian}

Berdasarkan penelitian yang digunakan yaitu Penelitian Tindakan Kelas (PTK) maka prosedur penelitian ini dikemukakan oleh Arikunto (2015:42) bahwa Penelitian Tindakan Kelas memiliki empat tahapan lazim yaitu: 1) Perencanaan, 2) Pelaksanaan, 3) Pengamatan, 4) Refleksi. Berikut merupakan penjelasan dan bagan Penelitian Tindakan Kelas (PTK).

\section{HASIL PENELITIAN DAN PEMBAHASAN}

Hasil belajar siswa secara klasikal pada pretes yaitu siswa yang tuntas 5 orang dengan persentase $14.29 \%$ dan yang tidak tuntas 30 orang siswa dengan persentase $85.71 \%$. setelah dilakukan tindakan pada siklus I hasil belajar siswa secara klasikal meningkat dengan 21 orang siswa dengan persentase $60 \%$ dan yang tidak tuntas 14 orag siswa dengan persentase $40 \%$. Namun pelaksanaan tidakan siklus I belum mencapai tingkat ketuntasa yang telah ditetepkan yaitu $80 \%$ makan dilakukan kembali tindakan perbaikan yang dilakukan pada tindakan siklus II. Tindakan yang dilakukan pada siklus II mengalami peningkatan dengan jumlah 30 orang siswa yang tuntas dengan persentase $85.71 \%$ sedangkan yang tidak tuntas terdapat 5 orang siswa dengan persentase $14.29 \%$ dengan demikian tindakan yang dilakukan pada tiap siklus mengalami peningkatan dan mencapai hasil belajara yang telah ditetapkan yaitu $80 \%$ atau dengan kategori baik sekali. Untuk mengetahui perubahan peningkatan pada tindakan tiap siklus maka dapat di lihat pada tabel 4.14 di bawah ini:

\begin{tabular}{l|l}
\hline No & Tes \\
\hline
\end{tabular}
Jumlah Siswa yang Tuntas Persentasi Keterangan 


\begin{tabular}{|l|l|l|l|l|}
\hline 1 & Pretes & 5 & $14.29 \%$ & \multirow{3}{*}{ Meningkat } \\
\hline 2 & Siklus I & 21 & $60 \%$ & \\
\hline 3 & Siklus II & 30 & $85.71 \%$ & \\
\hline
\end{tabular}

Dari tabel di atas dapat di simpulkan bahwa adanya peningkatan hasil belajar siswa secara klasikal dan dapat di lihat pada perbadingan antar pretes, siklus I, dan siklus II pada mata pelajaran IPA dengan materi sistem pencernaan makanan pada manusia dengan menggunakan model pembelajaran kooperatif tipe STAD dan telah mencapai ketuntasan klasikal yaitu $80 \%$.

\section{PENUTUP}

\section{Kesimpulan}

Bardasarkan hasil analisis data yang dilakukan oleh peneliti dengan menggunakan model pembelajaran kooperatif tipe STAD pada mata pelajaran IPA pada materi tentang sistem pencernaan makanan pada manusia di kelas V SD St. Antonius Bangun Mulia dapat disimpulkan sebagai berikut:

Pelaksanaan pembelajaran IPA dengan menggunakan model pembelajaran kooperatif tipe STAD pada materi sistem pencernaan makanan pada manusia dapat meningkatkan keterapilan guru dengan kategori baik sekali dimana kegiatan observasi guru pada siklus I yaitu $60 \%$ dan meningkat pada siklus II menjadi $86 \%$. Hasil kegiatan observasi siswa pada siklus I yaitu $60 \%$ dan meningkat pada siklus II menjadi $82 \%$.

Dengan menggunakan model pembelajaran kooperatif tipe STAD pada materi sistem pencernaan makanan pada manusia telah meningkat dan dapat di lihat dari rata-rata siklus I dengan nilai 73,71 dan siklus II menjadi 85,48.

Implikasi

Hasil belajar yang di peroleh dalam penelitian ini menunjukkan bahwa adanya peningkatan hasil belajar IPA siswa dengan menggunakan model pembelajaran kooperatif tipe STAD pada materi sistem pencernaan makanan pada manusia. Pada dasarnya dengan menggunakan model pembelajaran yang tepat merupakan salah satu faktor yang dapat meningkatkan hasil belajar siswa karena dengan model pembelajaran siswa siswa di ajak untuk saling berkerja sama, sehingga tujuan pembelajaran dapat tercapai. Dalam hal ini apa bila guru menggunakan model pembelajaran yang kurang tepat selama pelaksanaan pembelajaran berlangsung dapat mengakibatkan hasil belajar siswa menjadi rendah oleh karena itu implikasi dalam penelitian ini adalah sebagai berikut:

Bagi guru, penggunaan model pembelajaran kooperatif tipe STAD dapat di gunakan guru sebagai acuan dalam meningkatkan hasil belajar siswa dan

Bagi siswa, penggunaan model pembelajaran kooperatif tipe STAD membawa dampak positif dalam meningkatkan hasil belajar siswa, dan mengajak siswa untuk saling berkeja sama dan saling membantu antara siswa yang satu dengan yang lainnya dan siswa lebih termotivasi dalam mengikuti proses pembelajaran di kelas.

\section{Keterbatasan Penelitian}

Dalam penelitian ini terdapat keterbatasan yang diharapkan akan memberikan kesempatan bagi peneliti lainnya untuk melakukan penelitian yang sama yang akan berguna bagi perluasan wawasan keilmuan: Adapun keterbatasan penelitian ini adalah: 
1. Subjek penelitian ini berasal dari sekolah yaitu SD St. Antonius Bangun Mulia Medan Kecamatan Medan Amplas, oleh karena itu hasil penelitian ini belum tentu sesuai dengan sekolah lainnya karena sekolah SD St. Antonius Bangun Mulia belum tentu memiliki karasteristik yang sama.

2. Penelitian ini memiliki waktu yang relatif singkat sehingga hasil belajar siswa akan berdampak pada hasil yang kurang maksimal.

3. Penelitian ini memiliki keterbatasan pada penggunaan model pembelajaran kooperatif tipe STAD untuk meningkatkan hasil belajar IPA siswa pada materi sistem pencernaan makanan pada manusia. Dalam penelitian ini banyak faktor yang memungkinkan adanya pengaruh terhadap hasil belajar siswa misalnya lingkungan sekolah, keluarga, kemampuan peserta didik dalam mengikuti pembelajaran di kelas. Dengan demikian kondisi-kondisi ini bisa saja termasuk dalam mempengaruhi hasil belajar siswa.

\section{Saran}

Dari hasil penelitian dan kesimpulan diatas maka peneliti mengajukan beberapa saran sebagai berikut:

1. Bagi guru di himbau agar dapat menggunakan model atau metode pembelajaran pada saat melaksanakan pembelajaran sehingga dapat meningkatkan hasil belajar siswa.

2. Bagi pihak sekolah diharapkan agar lebih memperhatikan segala fasilitas yang ada di sekolah demi memperbaiki proes pembelajaran.

3. Kepada peneliti selanjutnya agar melakukan penelitian yang sejenis secara tuntas dengan menggunakan model pembelajaran kooperatif tipe STAD.

\section{DAFTAR PUSTAKA}

Aqip, Zainal, dkk. 2016. Penelitian Tindakan Kelas.Bandung: Yrama Widya Arikunto, Suharsimin, dkk. 2015. Penelitian Tindakan Kelas. Jakarta: Bumi Aksara.

Arikunto, Suharsimin. 2016. Dasar-Dasar Evaluasi Pendidikan. Jakarta: Bumi Aksara.

Fuziyanti Wahyuni Sri (2012) Upaya meningkatkan minat belajar siswa dalam menggunakan model STAD ( Student Teams Achievement Division) pada pelajaran IPS di kelas IV SD Negeri 067691 Medan.T.A. 2011/2012

Hamdani. 2010. Strategi Belajar Mengajar. Bandung: CV Pustaka Setia.

Hamruni. 2013. Strategi Pembelajaran, Yogyakarta: Insan Madani.

Herlanti, Yanti, dkk. 2010. Ilmu Pengetahuan Alam IPA Kelas 5 Sekolah Dasar Semester Kedua. Jakarta: Yudhistira

Julianto, 2015, Penerapan Model Pembelajaran Kooperatif Tipe STAD untuk Meningkatkan Hasil Belajar pada Sekolah Dasar, Surabaya: Vol 2, No 3:

http://jurnalmahasiswa.unesa.ac.id/index.php/jurnal-penelitianpgsd/article/view/12172. [6 April 2017].

Jihad, Asep dan Abdul Haris. 2012. Evaluasi Pembelajaran. Yogyakarta: Multi Pressindo.

Muslahin, 2013, Upaya Meningkatkan Hasil Belajar Melalui Model Pembelajaran Kooperatif Tipe STAD pada Mata Pelajaran IPA Kelas VI Semester I SDN Sidodadi I/153, Surabaya: Vol 1, No 2: 1. 
http://jurnalmahasiswa.unesa.ac.id/index.php/jurnal-penelitian pgsd/article/view/3063. [6 April 2017].

Ningsih Yulia Nova (2016) Meningkatkan hasil belajar siswa pada mata pelajaran IPA dengan menggunakan model pembelajaran kooperatif tipe STAD kelas VI SDN 101766 Bandar Setia

Rustaman, Nuryani, dkk, 2014, Materi dan Pembelajaran IPA, Tangerang Selatan: Universitas Terbuka.

Sahertian, Piet A. 2010. Konsep Dasar dan Teknik Suvervisi Pendidikan Dalam Rangka Pengembangan Sumber Daya Manusia. Jakarta: Rineka Cipta.

Samatowa, Usman, 2016, Pembelajaran IPA di Sekolah Dasar, Jakarta: PT Indeks.

Shoimin, Aris, 2016, 68 Model-model Pembelajaran Inovatif dalam Kurikulum 2013, Yogyakarta: Ar-Ruzz Media.

Slavin,E Robert, 2005, Kooperative Learning, Bandung: Nusa Indah.

Sajaya, Wina. 2013. Penelitian Tindakan Kelas. Jakarta: Kencana.

Sugiyono.2012. Metode Penelitian Pendidikan Pendekatan Kuantitatif, Kualitatif, dan $R \& D$. Bandung: Alfabeta

Sujana, Nana. 2009. Penelitian Hasil Proses Belajar Mengajar. Bandung: PT Remaja Rosdakarya

Suhemi Eva (2016) Upaya meningkatkan hasil belajar IPA melalui metode pembelajaran kooperatif tipe STAD di SD Negeri 173467 Sitinjak Temba Humbang Hasundutan.

Sulistyanto, Heri, dkk, 2008, Ilmu Pengetahuan Alam untuk SD dan MI Kelas V, Jakarta: Pusat Perbukuan Departemen Pendidikan Nasional.

Susanto, Ahmad,2016, Teori Belajar \& Pembelajaran di Sekolah Dasar, Jakarta: Prenadia Media.

Tampubolon, Saur, 2014, Penelitian Tindakan Kelas, Jakarta: Erlangga.

Trianto, 2011, Mendesain Model Pembelajaran Inovatif-Progresif, Jakarta: Prenada Media. 